W zakończeniu dysertacji (ss. 307-324) Autor zbiera wnioski wynikające z dobrze przeprowadzonej analizy źródeł. W pracy uderza przejrzystość i jasność przekazu. Rzetelnie potraktował Autor stan badań. Język pracy jest jasny i logiczny. Jest sporo powtórzeń, które być może ułatwiają percepcję materiału. Autor swobodnie porusza się w źródłach i opracowaniach. Rozprawa ks. Stanisława Strękowskiego stanowi zatem istotny wkład w rozwój badań naukowych, zwłaszcza nad myślą św. Grzegorza z Nyssy.

Ks. Augustyn Eckmann - Lublin, KUL

\title{
Agnieszka KIJEWSKA, Święty Augustyn, seria: Myśli i Ludzie, Warszawa 2007, Wydawnictwo „Wiedza Powszechna”, ss. 364.
}

Świętym Augustynem (354-430), wielkim uczonym i biskupem Hippony urodzonym w Tagaście oraz jego twórczością, interesowano się już za jego życia; znany był na Zachodzie i Wschodzie. Wywarł ogromny wpływ na kulturę Europy. W ciągu wieków powstało wiele prac na temat jego osoby, pisarskiej spuścizny i nauki. Na tym polu nie pozostają w tyle również polscy uczeni (por. S. Longosz - W. Stawiszyński, Św. Augustyn w polskich studiach. Materiały bibliograficzne, VoxP 23:2003, t. 44-45, 521-623). Literatura poświęcona w ogóle św. Augustynowi jest bogata tak pod względem ilości, jak i różnorodności poruszanej problematyki. Każda jednak nowa pozycja, zwłaszcza traktująca go w sposób dotąd niedostrzeżony, jest przyjmowana z ogromnym zainteresowaniem. Wydaje się, że właśnie taką jest książka p. prof. Agnieszki Kijewskiej nosząca krótki tytuł, po prostu Święty Augustyn. Wiadomo, że św. Augustyn to postać ciekawa, barwna i wielka, ale i przybliżenie jego osoby i myśli współczesnemu czytelnikowi stało się przedmiotem znakomitego studium Autorki. Prof. A. Kijewska z jednej strony wykorzystuje liczne dobre opracowania, z drugiej natomiast oddaje głos samemu św. Augustynowi, przytaczając urywki jego dzieł, zwłaszcza Wyznań. Nade wszystko jednak istotne są własne przemyślenia Autorki i sposób ich przekazania. Wydaje się, że Autorka jest zafascynowana Augustynem człowiekiem i myślicielem. Opisując augustyńską odyseję ku Bogu, trafnie zwraca uwagę na lekturę dzieł: Hortensjusza Cycerona, księgi platoników i Pismo Święte, których treść w sposób zasadniczy wywarła wpływ na duchowy rozwój Augustyna z Tagasty. Lektura Cycerona zmieniła nastawienie jego umysłu i serca, roznieciła w nim umiłowanie mądrości. Lektura „ksiąg platoników” z kolei zaowocowała nawróceniem dokonanym na płaszczyźnie intelektualnej, retor afrykański zaczął wnikać w głębię swej istoty, poznał neoplatońską drogę wstępowania duszy. Wreszcie lektura Pisma Świętego, zwłaszcza listów św. Pawła, doprowadziła go do całkowitego nawrócenia do chrześcijaństwa i uzyskania pełnej wiary. Pisząc o Augustynie, 
Autorka czyni ustawicznie bardzo ciekawe i potrzebne ekskursy, wyjaśniające kwestie związane z głównym przedmiotem badań i przekazu, jak np. podaje dzieje manicheizmu, omawia w trakcie analiz tekstów Doktora Kościoła jakby „po drodze” różne kierunki filozoficzne, zwraca też uwagę na pewne wyrażenia łacińskie, które charakteryzują Augustyna retora, jak np. na stronie 86, przypis 76: „Łapczywie więc chwyciłem (avidissime arripui) w ręce czcigodne Pisma natchnione przez Ducha Świętego, a zwłaszcza teksty Pawła”. Podaje też za Augustynem ciekawostki kulturowe, choćby taką, iz Ambroży nigdy nie czytał na głos, podczas gdy ta metoda czytania na Zachodzie upowszechniła się dopiero w X wieku. Opis ten znajdujący się w Confessiones (VI 3) Augustyna „jest pierwszym znanym przykładem w literaturze Zachodu” (s. 66).

Trzeba powiedzieć, że książka p. prof. Agnieszki Kijewskiej składa się z dwóch części. W pierwszej części (ss. 5-216) ukazała dzieciństwo i młodość Augustyna, jego związki z manicheizmem, fazę sceptycyzmu, w kręgu neoplatoników mediolańskich, nawrócenie, chrześcijańskie otium i dialogi z Kasycjakum. W tej też części zanalizowała naukę wielkiego Afrykańczyka na temat duszy ludzkiej i pamięci, Boga Stwórcy i Trójcy Świętej oraz Biblii i dzieła stworzonego. Druga część (ss. 233-361), stanowi jakby dopełnienie tego, co wcześniej zostało napisane i obejmuje wybór tekstów Doktora Kościoła na tematy poruszane w części pierwszej. Autorka podała też ważniejsze daty z życia św. Augustyna (ss. 217-218) oraz bibliografię (ss. 219-231), w której zawarła najważniejsze pisma św. Augustyna i literaturę przytaczaną oraz opracowania.

Książka świadczy o wielkiej erudycji Autorki, profesora nauk humanistycznych, historyka filozofii starożytnej i średniowiecznej, która doskonale znając język łaciński, niejednokrotnie przeprowadza dobrą krytyczną analizę tekstu. Autorka traktuje każdy tekst oddzielnie i odczytuje go w kontekście różnych dzieł św. Augustyna. Praca prof. Agnieszki Kijewskiej ma charakter analityczny, ale w sumie Autorka daje dobrą syntezę życia i myśli wielkiego Doktora Kościoła. Komunikatywny język książki sprawia, że czyta się ją przyjemnie jako ciekawą lekturę. Augustyńskie zaś przesłanie zdecydowanie przekracza obszar afrykański, w którym żył. Kieruje on swoje orędzie do człowieka krytycznego, ale szczerze szukającego, do człowieka wierzącego i każdego czasu.

$$
\text { Ks. Augustyn Eckmann - Lublin, KUL }
$$

\section{EWANGELIA JUDASZA, wstęp, thumaczenie z koptyjskiego i komentarz Wincenty MYSZOR, Katowice 2006, Księgarnia św. Jacka, ss. 96.}

1 lipca 2004 r. podczas VIII Międzynarodowego Kongresu Koptologicznego w Paryżu R. Kasser oficjalnie ogłosił odkrycie tzw. „kodeksu Tchacos” (od nazwiska ostatniej właścicielki Friedy Nussberger-Tchacos), zawierającego 